\title{
Study on Adaptability, Productive Performance and Constraints of Vanaraja Birds in Backyard System of Rearing at Udalguri District of Assam, India
}

\author{
D. Bharali ${ }^{1}$, D. Borah ${ }^{2}$, P. Rajbonshi ${ }^{2}$ and L. J. Dutta ${ }^{3}$
}

${ }^{1}$ Livestock Research Station, Assam Agricultural University, Mondira, Kamrup, Assam, India

${ }^{2}$ Krishi Vigyan Kendra, Assam Agricultural University, Lalpool, Udalguri, Assam, India

${ }^{3}$ College of Veterinary Science, Assam Agricultural University, Khanapara, Assam, India,

*Corresponding author

\section{A B S T R A C T}

\section{Keywords}

Vanraja bird, vaccination, adaptability, constraints

Article Info

Accepted: 05 February 2020 Available Online: 10 March 2020
The present study was conducted on 600 Vanaraja birds reared in backyard system at Udalguri district of Assam under Tribal Sub Plan project. The overall body weight of male and female Vanaraja birds at $40^{\text {th }}$ week of age was recorded as $3980.53 \pm 330.74$ and $3080.55 \pm 143.22$ grams, respectively. Age of hen at first egg laying was $162.55 \pm 11.43$ days. Egg production of Vanaraja bird was recorded as $146 \pm 14.66$ per bird per year. The benefit cost ratio of male at 16 week and female Vanaraja bird at 1 year was recorded as 2.05:1 and 1.96:1, respectively.

\section{Introduction}

The rapid growth of poultry sector in our country during the last 3 to 4 decades has been almost exclusively dependent on appearance of intensive or commercial type poultry enterprise, often located in urban or semi urban areas. Rural and tribal areas have received little attention in this sector, creating a large gap in the availability of highly nutritious egg and chicken meat between urbanites and malnourished rural/tribal people. Only the solution is backyard farming in rural and tribal areas.

The backyard farming will certainly improve the economic status of a large majority of tribal rural families from lower socioeconomic strata in the rural and tribal areas. Backyard farming fulfils a wide range of functions as it provides meat and eggs at an earlier age of bird when reared improved variety, chicken for traditional ceremonies, pest control and petty cash-while requiring minimal external inputs, minimal human attention, and causing minimal disruption to the environment. The 
demand of poultry and its products in India is very high as it has no ethical issues. Introduction of improved breeds, strains, varieties shows an increasing trend in the production.

Vanaraja is one of the improved variety dual purpose bird developed by Project Directorate on Poultry (ICAR), Hyderabad suitable for backyard or range farming system (Dey et al., 2019) and income generating activity especially for the rural women (Niranjan et al., 2008). Keeping view on above mentioned advantages, Vanaraja birds were introduced in few tribal villages of the Udalguri district of Assam to study their adaptability in this locality, reproductive ability and economic viability under traditional backyard rearing system.

\section{Materials and Methods}

The present study was conducted at Udalguri district under Krishi Vigyan Kendra, Udalguri from 2016 to 2018. Six hundred day old Vanaraja birds were provided to 40 tribal women of Udalguri district under tribal sub plan project. The selected farm women were trained on "Improved poultry rearing scientifically in backyard system" before providing the chicks.

The day old chicks were reared under brooder during first 30 days. After that birds were reared in backyard system. Age at sexual maturity, egg production, egg weight, mortality rate, and carcass traits was recorded as per standard method.

\section{Health care}

Standard vaccination, deworming and supplementation was done according to the following schedule (Table1)

\section{Feeding system}

Natural vegetation, kitchen waste was excellent source of food in backyard. Besides that adult birds were provided concentrate feed $100 \mathrm{~g}$ daily.

\section{Performance parameter}

Live body weight of birds were recorded at 4 weeks interval till 40 week of age viz. at 0 day, 8 week, 12 week, 16 week, 20 week, 24 week 28 week, 30 week 34 week and 40 week of age and average body weight was calculated. Age of hen at first egg laying, number of egg production, egg weight and mortality was also recorded. The cost of expenditure were recorded as per existing market price for different inputs to assess the cost benefit of rearing Vanaraja and local birds. Means and standard error of various traits were calculated using standard statistical methods (Snedecor and Cochran, 1994).

\section{Constraints}

Different constraints faced by the farmers during rearing of Vanaraja birds in Udalguri district of Assam were recorded.

\section{Results and Discussion}

The results of body weight at different stage and performance and reproductive traits of Vanaraja birds have been presented in table 2 .

The mean body weight of male and female Vanaraja birds at 0 day, 8 week, 12 week, 16 week, 20 week, 24 week 28 week, 30 week, 34 week and 40 week of age were recorded as $40.36 \pm 1.2$ and $38.32 \pm 0.73 ; 850.34 \pm 87.50$ and $580.65 \pm 95.05 ; 1680.45 \pm 117.34$ and $950.45 \pm 122.45 ; 2092.66 \pm 174.45$ and $1625.54 \pm 204.75 ; 2565.62 \pm 205.30$ and $1910.33 \pm 184.35 ; 2830.88 \pm 260.08$ and $2330.06 \pm 176.54 ; 3160.44 \pm 198.20$ and $2620.87 \pm 156.41 ; 3415.77 \pm 240.05$ and $2815.33 \pm 146.55 ; 3680.33 \pm 310.40$ and $2970.40 \pm 138.66$ and $3980.53 \pm 330.74$ and $3080.55 \pm 143.22$ grams, respectively. In 
contrast to the present findings, Kalita et al., (2012) Sonia et al., (2019) and Dutta et al., (2019) recorded higher body weight of Vanaraja bird at different ages. Mortality of Vanraja birds till 5, 20 and 40 week of age in the present study was recorded as 7.66, 6.67 and 3.44 per cent, respectively, which was higher than the findings of Kalita et al., (2012) and Dutta et al., (2019).

Age at first egg laying of Vanaraja bird was
$162.55 \pm 11.43$ days. Egg production was recorded as $146 \pm 14.66$ per bird per year while the egg weight at 32 and 40 week was recorded as $46.8 \pm 1.98$ and $60.5 \pm 3.66$, respectively. The dressing percentage of the bird used for meat purposes was $69.66 \pm 3.44$. The present findings in terms of egg weight, egg production was in agreement with the findings of Kalita et al., (2012) while Sharma and Hazary (2002) reported lower egg weight at 40 weeks of age.

Table.1 Vaccination, deworming and supplementation Schedule adopted for

Vanaraja birds at Udalguri district of Assam

\begin{tabular}{|c|c|c|c|c|}
\hline Age & $\begin{array}{l}\text { Supplementation/ } \\
\text { Deworming }\end{array}$ & Vaccination & Booster & Interval \\
\hline 0 day & Electrolyte & Marek's disease & - & - \\
\hline Upto 3 days & Electrolyte & - & - & - \\
\hline 4-7 days & Vitamins & $\begin{array}{c}\text { Ranikhet Disease F1 } \\
\text { strain }\end{array}$ & - & - \\
\hline 8-10 days & Antibiotics & - & - & - \\
\hline 12-14 days & Liver tonic & $\begin{array}{c}\text { Infectious Bursal } \\
\text { disease }\end{array}$ & - & - \\
\hline 15-17 days & Anti coccidiosis & - & - & - \\
\hline 18-20 days & Vitamins & - & - & - \\
\hline 21-23 days & Antibiotics & - & - & - \\
\hline 25 -27 days & Anticoccidiosis & - & - & - \\
\hline 28-30 days & Vitamins & $\begin{array}{c}\text { Ranikhet Disease F1 } \\
\text { strain }\end{array}$ & - & - \\
\hline 37-40 days & Liver tonic & - & - & 15-20 days \\
\hline 60-70 days & Vitamins & Ranikhet Disease R2B & - & - \\
\hline 70-80 days & Vitamins & Fowl pox & - & - \\
\hline 16-17 weeks & Vitamins & Ranikhet Disease R2B & $\begin{array}{l}\text { Every } 6 \\
\text { months }\end{array}$ & - \\
\hline
\end{tabular}


Table. 2 Productive, reproductive parameters and economics of Vanaraja birds reared in backyard system at Udalguri district of Assam

\begin{tabular}{|c|c|c|}
\hline Parameters of study & Male Vanaraja bird & Female Vanaraja bird \\
\hline \multicolumn{3}{|l|}{$\begin{array}{l}\text { Body weight of female duck (Mean } \pm \\
\text { S.E.) gram }\end{array}$} \\
\hline 0 day & $40.36 \pm 1.2$ & $38.32 \pm 0.73$ \\
\hline 8 week & $850.34 \pm 87.50$ & $580.65 \pm 95.05$ \\
\hline 12 week & $1680.45 \pm 117.34$ & $950.45 \pm 122.45$ \\
\hline 16 week & $2092.66 \pm 174.45$ & $1625.54 \pm 204.75$ \\
\hline 20 week & $2565.62 \pm 205.30$ & $1910.33 \pm 184.35$ \\
\hline 24 week & $2830.88 \pm 260.08$ & $2330.06 \pm 176.54$ \\
\hline 28 week & $3160.44 \pm 198.20$ & $2620.87 \pm 156.41$ \\
\hline 32 week & $3415.77 \pm 240.05$ & $2815.33 \pm 146.55$ \\
\hline 36 week & $3680.33 \pm 310.40$ & $2970.40 \pm 138.66$ \\
\hline 40 week & $3980.53 \pm 330.74$ & $3080.55 \pm 143.22$ \\
\hline \multicolumn{3}{|l|}{ Mortality (Combined sex) } \\
\hline 0-5 week of age (\%) & 7.66 & \\
\hline 6-20 week of age (\%) & 6.67 & \\
\hline 21-40 week of age (\%) & 3.44 & \\
\hline Age at first egg laying (days) & $162.55 \pm 11.43$ & \\
\hline Egg production (number / bird / year) & $146 \pm 14.66$ & \\
\hline \multicolumn{3}{|l|}{ Egg weight (g) at } \\
\hline 32 week & $46.8 \pm 1.98$ & \\
\hline 40 week & $60.5 \pm 3.66$ & \\
\hline Dressing percentage (Combined sex) & $69.66 \pm 3.44$ & \\
\hline \multicolumn{3}{|l|}{ Earning } \\
\hline From female bird (Rs.) & 697 & \\
\hline From male bird at 16 week (Rs.) & 256 & \\
\hline \multicolumn{3}{|l|}{ B:C ratio } \\
\hline Male bird & $2.05: 1$ & \\
\hline Female bird & $1.96: 1$ & \\
\hline
\end{tabular}


The benefit cost ratio of male and female Vanaraja bird was recorded as 2.05:1 and 1.96:1 at 16 week and 1 year, respectively, which indicates that the rearing of Vanaraja bird is economic and beneficial for both meat and egg purposes. The overall results were corroborated with the findings reported by Buragohain et al., (2005) while Zuyie et al., (2009) has reported a slight different result from the present findings. But PDP, Hyderabad has reported sexual maturity as 145.3 days and 40 week body weight as 3.40 $3.80 \mathrm{~kg}$. The mortality up to first lay was recorded as 11.98 percent $(9.58-16 \%)$ which indicate their adaptability in rural areas of Udalguri district of Assam. The egg weight and body weight at 10 months of age was lower than the report of PDP, Hyderabad. This may be due to the poor management and feeding resource at village level.

\section{Constraints faced by farmers rearing vanaraja birds}

The problems faced by the farmers in rearing Vanaraja birds were destruction of vegetation, hatching of eggs in scattered places rather than nest, poor brooding habit and cannibolism when reared by providing less space for the birds.

These findings were in agreement with the findings of Dutta et al., (2019).

It is perceptible from the present study that the Vanaraja birds adapted well in agroclimatic condition of Udalguri district of Assam. The productivity in terms of growth and egg production was found superior than the local birds. Thus, it can be concluded that under backyard system of rearing, Vanaraja birds may considerably contribute to the overall economic return and give nutritional security to the rural poor farmers of the region.

\section{References}

Buragohain, R., Ahmed, F. A., Ghosh, M. K. and Bhattacharya, M. 2005. Productive performance of Vanaraja birds in high altitude areas of Arunachal Pradesh under semi-scavenging system of rearing. Poultry Punch. 22 (1):37-45.

Dey, S.; Samanta, R.; Pan, S.; Debnath, B.and Debbarma, A. 2019. Factors Associated with Embryonic Mortality of Eggs of Vanaraja Breeder Chicken Reared on Deep Litter System. Int.J.Curr.Microbiol.App.Sci. 8 (04): 525-532.

Dutta, L.J.; Bharali, D.; Saikia, T and Deka, N. 2019. Performance, constraints and impact of Vanaraja birds rearing in Lakhimpur district of Assam. The North East Veterinarian. 18 (4): 29-31.

Kalita, N.; Baruah, N.; Pathak, N. and Islam, R. 2012. Performance of Vanaraja birds under intensive system of management in Assam. Indian J. Poultry Sci. 47(1): 125-127.

Niranjan, M.; Sharma, R.P.; Rajkumar, U.; Chatterjee, R.N.; Reddy, B.L. and Bhattacharyya, T.K. 2008. Egg quality traits in chicken varieties developed for backyard poultry farming in India. Livestock Research for Rural Development. 20(12).

PDP, Hyderabad. Project Directorate on Poultry, Rajendranagar, Hyderabad.

Sharma, R. P. And Hazary, R.C. 2002. Development and propagation of synthetic breeds for backyard poultry farming. Proceedings of National Workshop on characterization and conservation of indigenous poultry germplasm, Central Agric. Res. Institute, Andaman, pp:104.

Sonia, C.; Singh, M.N.; Sailo, B.; Sharma, B.K.; Dilrash, M.; Gangmei, D. and Tania, Ch. 2019. Vanaraja and Srinidhi chicken: An alternative backyard 
poultry birds for Manipur state. The North East Veterinarian. 18 (4): 32-34.

Snedecor, G.W. and Cochran, W.G.1994. Statistical Methods. $6^{\text {th }}$ edn., Oxford \& IBH Publishing Co., Calcutta.

Zuyie, R., Sharma, V.B., Bujarbaruah, K. M. and Vidyarthi, V. K. 2009. Performance of Vanaraja birds under extensive system of rearing at different altitude of Nagaland. Indian Journal of Poultry Science, 44 (3) : 411-413

\section{How to cite this article:}

Bharali. D, D. Borah, P. Rajbonshi and Dutta. L. J. 2020. Study on Adaptability, Productive Performance and Constraints of Vanaraja Birds in Backyard System of Rearing at Udalguri District of Assam, India. Int.J.Curr.Microbiol.App.Sci. 9(03): 986-991. doi: https://doi.org/10.20546/ijcmas.2020.903.116 